九州大学学術情報リポジトリ

Kyushu University Institutional Repository

\title{
Studies on the Holopulp : II. Inhibitors in the Peracetic Acid Delignification of Certain Non- Woody Plants
}

Ai, Tran Van

Laboratory of Wood Chemistry, Faculty of Agriculture, Kyushu University

Sakai, Kokki

Laboratory of Wood Chemistry, Faculty of Agriculture, Kyushu University | Laboratory of Wood Chemistry, Faculty of Agriculture, Kyushu University

Kondo, Tamio

Laboratory of Wood Chemistry, Faculty of Agriculture, Kyushu University

https://doi.org/10.5109/23649

出版情報: 九州大学大学院農学研究院紀要. 22 (1/2)，pp.41-52，1977-10. Kyushu University バージョン：

権利関係 : 
J. Fac. Agr.. Kyushu Univ., 22, 41-52 (1977)

\title{
Studies on the Holopulp \\ II. Inhibitors in the Peracetic Acid Delignification of Certain Non-Woody Plants
}

\author{
Tran Van Ai, Kokki Sakai and Tamio Kondo \\ Laboratory of Wood Chemistry, Faculty of Agriculture, \\ Kyushu University 46-08, Fukuoka 812
}

(Received July 19, 1977)

\begin{abstract}
Rice straw (Oryza sativa L.). moso bamboo (Phyllostachys pubescens Mazel), barley straw (Hordeum vulgare L.), and bagasse (Saccharum officinarum L.) were subjected to oxidative delignification with sodium chlorite and peracetic acid. All the samples examined could be delignified almost completely by chlorite method. However, in the peracetic acid treatment, it was found that only barley straw and bagasse could be delignified. The peracetic acid delignification of rice straw and moso bamboo was unsuccessful when peracetic acid dosage was lower than $300 \%$. Even at higher peracetic acid dosage, the delignification of rice straw could not take place, although that of bamboo was fairly accomplished. About one half of rice straw's lignin remained after peracetic acid delignification. It was found that extraction with diluted hydrochloric acid would facilitate the peracetic acid delignification of bamboo and rice straw, and that the extractable iron compound was the principal inhibitor. Bamboo contained $0.02 \%$ of extractable $\mathrm{Fe}^{2+}$ compound and rice straw $0.02 \%$ of $\mathrm{Fe}^{2+}$ and $\mathrm{Fe}^{3+}$ in approximately equal amounts. In addition to iron compound, manganese salt was found to be the co-inhibitor of rice straw's peracetic acid delignification. Such inhibitors played the role of catalysts in the decomposition of peracetic acid.
\end{abstract}

\section{INTRODUCTION}

It is reported in the previous work (Ai et al., 1977) that holopulps prepared from wood chips and Asplund fibers were slow to beat and had higher strength properties than conventional chemical pulps prepared from the same materials. It is also known that straws are not heavily lignified and can be pulped under less drastic conditions than wood. Besides, the loose structure of straws allow easy diffusion and penetration of chemicals. These significant phenomena made it desirable to extend the study of holopulp to other natural fibrous materials than woody fibers.

In the present study, materials of four non-woody plants, namely, rice straw, bamboo, barley straw, and bagasse were subjected to holopulping using sodium chlorite and peracetic acid as delignification reagents. It was observed that barley straw, bagasse, and moso bamboo could be delignified with both chlorite and peracetic acid methods. Rice straw, on the other hand, could be delignified only with chlorite and not with peracetic acid. About one half of rice straw's 
lignin remained after the peracetic acid treatment.

As far as known, there is no work pointing out any chemicals or substances preventing the delignification of woody or non-woody plants by peracetic acid since this oxidant was first used in 1948 (Poljak, 1948) as a means of preparing holocellulose.

The purposes of the work reported here were thus: (1) to look for a suitable reagent for the pretreatment of rice straw, which would facilitate its post peracetic acid delignification and (2) to deal with the reason of why rice straw could not be delignified with peracetic acid.

\section{EXPERIMENTAL}

\section{Materials}

The rice straw (Oryza sativa L.) and moso bamboo (Phyllostachys pubescens Mazel) originated from the farm and the forest of Kyushu University, respectively. The rice straw was received in the autumn of 1975 and the moso bamboo, older than two years in age, in the spring of 1976. The barley straw (Hordeum vulgare L.) was the product of Fukuoka prefecture. The bagasse (Saccharum officinarum L.) originated in Okinawa and was not depithed. Both were taken in the spring of 1976. All the materials were ground in a Wiley mill, extracted with alcohol-benzene, air-dried, and denoted as original samples.

\section{Oxidative delignification}

Chlorite treatment was based on Wise method (Wise et al., 1946). Temperature was $70^{\circ} \mathrm{C}$.

Conditions of peracetic acid treatment were: liquor ratio, 30 ; temperature, $80^{\circ} \mathrm{C} ; \mathrm{pH}, 3.75\left(\mathrm{CH}_{3} \mathrm{CO}_{2} \mathrm{Na}\right.$ as buffer $)$. Peracetic acid dosage was varied from 50 to $500 \%$.

\section{Pretreatment of rice straw}

Prior to the peracetic acid treatment, rice straw was treated with various neutral, acidic, and alkaline reagents at a relatively high temperature for a short period. Conditions of these pretreatments are given in Table 1. From the results of preliminary experiments, the suitable concentration of each pretreatment reagent was, as shown in Table 3 , based on the selection of a minimum concentration which would give a high delignification percentage and a

Table 1. Pretreatment conditions of rice straw.

\begin{tabular}{|c|c|c|c|c|}
\hline \multirow[b]{2}{*}{ Reagents } & \multirow[b]{2}{*}{ Temp. (“C) } & & \\
\hline & & Time $(\min )$ & Liquor ratio & Conc. $(\%)$ \\
\hline $\begin{array}{l}\mathrm{HCl} \\
\mathrm{NaOH} \\
\mathrm{NaHCO}_{3} \\
\left(\mathrm{COONH}_{4}\right)_{2} \\
\mathrm{CH}_{3} \mathrm{COOH} \\
\text { Hot water }\end{array}$ & $\begin{array}{l}70 \\
70 \\
70 \\
80 \\
70 \\
80\end{array}$ & $\begin{array}{l}\mathbf{6 0} \\
10 \\
20 \\
60 \\
60 \\
\mathbf{6 0}\end{array}$ & $\begin{array}{l}50 \\
80 \\
50 \\
50 \\
\mathbf{5 0} \\
\mathbf{1 0}\end{array}$ & $\begin{array}{ll}0.01 & -0.2 \\
0.005-0 . & 2 \\
0.01 & -0.2 \\
\mathbf{0 . 1} & \mathbf{- 0 . 5} \\
0.01 & \mathbf{- 0 . 2}\end{array}$ \\
\hline
\end{tabular}


minimum loss of holocellulose yield resulting from the peracetic acid treatment of pretreated rice straw.

\section{Fractionation of $\mathrm{HCI}$ extract}

The $\mathrm{HCl}$ extract of rice straw was neutralized with mild sodium hydroxide, concentrated under reduced pressure and then centrifuged. The supernatant was dialyzed for $24 \mathrm{hrs}$. The fractionation scheme is shown in Figs. 3 and 4. Each resulting fraction was mixed with $\mathrm{HCl}$-extracted rice straw and those mixtures were treated with peracetic acid with a dosage of $400 \%$.

\section{Determination of inhibitory-effect}

In the present study, the inhibitory-effect of hydrochloric acid extract or heavy metals was determined as follows: five grams of rice straw were extracted with $250 \mathrm{mI}$ of $0.05 \% \mathrm{HCI}$ solution at $70^{\circ} \mathrm{C}$ for $1 \mathrm{hr}$ and then filtered. The fil trate was concentrated under reduced pressure to about $20 \mathrm{ml}$. The concentrated filtrate, or, the heavy metal weights calculated from five grams of rice straw meal, were mixed with two grams of alcohol-benzene extracted beech (Fagus crenata) wood meal. Such mixtures were treated with peracetic acid (dosage, $150 \%$ ) at $80{ }^{\circ} \mathrm{C}$ for $2 \mathrm{hrs}$. The residual Iignin content of the resultant holocellulose was regarded as the inhibitory-effect of hydrochloric acid extract or heavy metals on the peracetic acid delignification of rice straw.

\section{Analysis}

Solubilities in alcohol-benzene, cold water, hot water, and $1 \% \mathrm{NaOH}$, and ash determination were conducted according to the methods presented in Tappi standards (Browning, 1967). Silica determination followed the procedure of Tappi standard T224 su-70. Lignin content was determined as ash-free Klason Iignin. Pentosan was determined as phloroglucinol furfural.

Iron, manganese, and copper were measured by colorimetric and atomic absorption (Shimadzu Atomic Absorption Flame Photometer AA-610) methods. Ignition was carried out at $700-800^{\circ} \mathrm{C}$ in an electric furnace.

\section{RESULTS AND DISCUSSION}

\section{Analyses}

Included in Table 2 are analytical data of the non-woody plants examined. It is evident that the solubilities in alcohol-benzene, cold water, hot water, and $1 \% \mathrm{NaOH}$, and the ash and silica contents of straws were higher than those of moso bamboo and bagasse. The straws, however, had lower Iignin contents than bamboo and bagasse. Rice straw, especially, had the highest silica content and the lowest lignin content when compared with three other samples.

\section{Oxidative delignification behaviours}

The degrees of chlorite delignification of the four samples studied here are given in Fig. 1. It was observed that the delignification percentages of rice straw were lower than those of the three other samples. However, it seemed 
Table 2. Analytical data on the non-woody plants.

\begin{tabular}{|c|c|c|c|c|}
\hline Constituents & $\begin{array}{c}\text { Rice } \\
\text { straw }\end{array}$ & $\begin{array}{l}\text { Barley } \\
\text { straw }\end{array}$ & $\begin{array}{c}\text { Moso } \\
\text { bamboo }\end{array}$ & Bagasse \\
\hline $\begin{array}{l}\text { Alcohol-benzene ext. }(\%) \\
\text { Cold water ext. }(\%) \\
\text { Hot water ext. }(\%) \\
1 \% \text { NaOH ext. }(\%) \\
\text { Ash }(\%) \\
\text { Silica }(\%) \\
\text { Lignin (corrected for ash, } \%) \\
\text { Pentosan }(\%)\end{array}$ & $\begin{array}{r}7.0 \\
14.2 \\
14.4 \\
48.9 \\
15.2 \\
13.9 \\
14.7 \\
26.5\end{array}$ & $\begin{array}{r}7.2 \\
11.2 \\
15.3 \\
44.8 \\
6.7 \\
3.9 \\
18.7 \\
23.3\end{array}$ & $\begin{array}{r}3.8 \\
3.3 \\
4.3 \\
23.3 \\
0.3 \\
27.3 \\
22: 1\end{array}$ & $\begin{array}{r}1.5 \\
0.7 \\
2.5 \\
37.2 \\
2.8 \\
2.1 \\
21: 7 \\
27.3\end{array}$ \\
\hline
\end{tabular}

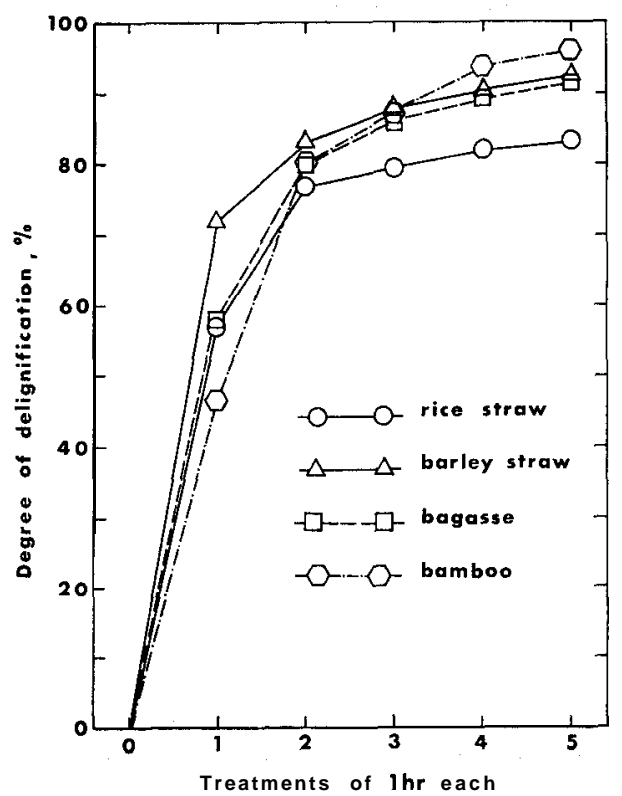

Fig. 1. Degree of chlorite delignitication of four non-woody plants.

likely that the chlorite method was widely suitable to all the samples examined because their delignification degrees were more than $80 \%$ at the end of the third treatment hour.

In contrast to the chlorite method, peracetic acid did not seem to be suitable to the delignification of rice straw and bamboo as seen from Fig. 2. At a peracetic acid dosage of $200 \%$, the degrees of delignification of rice straw and bamboo were 40.2 and $60.8 \%$ respectively. At a peracetic acid dosage of $400 \%$, while $94.1 \%$ of bamboo's lignin were removed, only $52.4 \%$ of lignin in rice straw were removed. Thus about one half of rice straw's lignin remained after its peracetic acid treatment. By that reason it was believed that there were inhibitors in rice straw which inhibited its peracetic acid delignification.

\section{Evidences showing the presence of inhibitors}

Usually rice straw was delignified by peracetic acid at a $\mathrm{pH}$ of 3.75 . How- 




Fig. 2. Degree of peracetic acid delignification of four non-woody plants.

ever, in order to study the effect of the $\mathrm{pH}$ of peracetic acid solution on the delignification of rice straw, this material was delignified at $\mathrm{pH} 6$ with other conditions unchanged. The residual lignin content of rice straw after delignified at $\mathrm{pH} 6$ was $8.8 \%$ or the delignification degree was $40.1 \%$. Thus the result indicated that at $\mathrm{pH} 6$ rice straw was more difficult to be delignified than at $\mathrm{pH}$ 3.75. This is probably due to the greater decomposition rate of peracetic acid at $\mathrm{pH} 6$ than at lower $\mathrm{pH}$.

Rice straw was then treated with various reagents prior to its usual peracetic acid delignification (see Experimental section). The peracetic acid dosage was $400 \%$, and the delignification percentages were determined in order to compare the effects of various pretreatment reagents. It is evident from Table 3 that $0.05 \% \mathrm{HCl}$ was the best pretreatment medium because the degree of delignification of rice straw treated sequentially with $0.05 \% \mathrm{HCl}$ and peracetic acid was the highest $(82 \%)$. This percentage was nearly the same as that attained by the chlorite method, about $84 \%$.

The above results suggest that rice straw contains something which may interfere with the peracetic acid delignification of rice straw and is extractable with diluted hydrochloric acid.

To verify this conclusion, the $\mathrm{HCl}$ extract was fractionated as shown in Fig. 3. Fractions $\mathrm{H} 1, \mathrm{H} 2$, and $\mathrm{H} 3$ were mixed again with $\mathrm{HCl}$-extracted rice straw prior to its peracetic acid treatment (peracetic acid dosage, $400 \%$ ). Re sidual lignin was then determined (Table 4). In comparison with residual lignin 
Table 3. Effect of various pretreatment reagents on the peracetic acid delignification* of rice straw.

\begin{tabular}{|c|c|c|c|c|c|c|c|c|}
\hline Reagents & & Untreated & $\begin{array}{c}\text { Hot } \\
\text { water }\end{array}$ & $\mathrm{CH}_{3} \mathrm{COOH}$ & $(\mathrm{COONH}$,$) ,$ & $\mathrm{NaHC}$ & $\mathrm{O}_{3} \mathrm{NaOH}$ & $\mathrm{H} \mathrm{HCl}$ \\
\hline $\begin{array}{l}\text { Conc. }(96) \\
\text { Res. lignin }(8)\end{array}$ & & $7 . \overline{0}$ & 5.6 & $\begin{array}{l}0.2 \\
4.4\end{array}$ & $\begin{array}{l}.4- \\
3.8\end{array}$ & $\begin{array}{l}0.05 \\
3.6\end{array}$ & $\begin{array}{l}0.005 \\
3.1\end{array}$ & $\begin{array}{l}0.05 \\
2.6\end{array}$ \\
\hline $\begin{array}{l}\text { Degree of } \\
\text { delignification }\end{array}$ & $(\%)$ & 52.4 & 61.9 & 70. 1 & 74.2 & 75.5 & 78.9 & 82.3 \\
\hline
\end{tabular}

* Peracetic acid dosage was 400\%



Fig. 3. Fractionation of $0.05 \% \mathrm{HCl}$ extract from rice straw.

Table 4. Residual lignin after the peracetic acid treatment of rice straw.

\begin{tabular}{|c|c|c|}
\hline Samples* & Residual lignin (\%) & Degree of delignification $(\%)$ \\
\hline S & 7.0 & 52.4 \\
\hline $\mathrm{R}$ & 2.6 & 82.3 \\
\hline $\mathrm{R}+\mathrm{H} 1$ & 5.8 & 60.5 \\
\hline $\mathrm{R}+\mathrm{H} 2$ & 4.2 & 71.4 \\
\hline $\mathrm{R}+\mathrm{H} 3$ & 3.6 & 75.5 \\
\hline
\end{tabular}

* See Fig. 3.

of peracetic acid treatment of $\mathrm{HCl}$-extracted rice straw (2.6\%), it seemed that the inhibitory-effect was almost recovered in fraction $\mathrm{H} 1$, and dispersed into fractions $\mathrm{HZ}$ and $\mathrm{H} 3$. As mentioned above, rice straw contained a large amount of ash and the ash content of the Klason lignin was consequently up to $60 \%$, based on the lignin weight. It should therefore be noted that the experimental errors in the ash determination of Klason lignin influenced largely the calculation of residual lignin of peracetic acid treated rice straw. In order to avoid these errors, the concept of "inhibitory-effect" (see Experimental section) was introduced and determined. Alcohol-benzene extracted beech wood meals (2g) were impregnated with fractions $\mathrm{H} 1, \mathrm{H} 2$, and $\mathrm{H} 3$ prior to the per. acetic acid treatment. Peracetic acid dosage for beech was $150 \%$. Fractions $\mathrm{H} 1, \mathrm{H} 2$, and $\mathrm{H} 3$ were seen clearly to inhibit the peracetic acid delignification of beech wood meal (Table 5). 
Table 5. The inhibitory-effect of various fractions in Fig. 3.

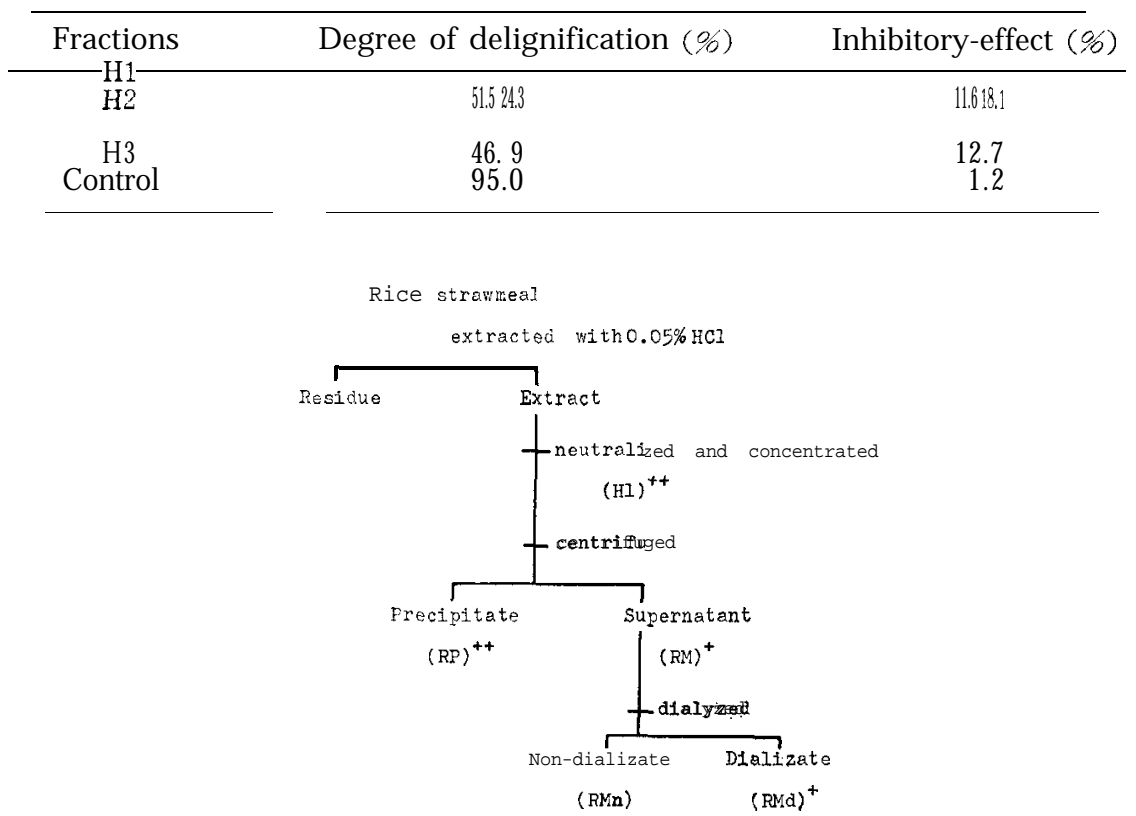

Fig. 4. Further fractionation of $0.05 \% \mathrm{HCl}$ extract from rice straw.

\section{Characterizations of inhibitors}

It was evident therefore that the $\mathrm{HCl}$ extract of rice straw contained inhibitors prohibiting the peracetic acid delignification of rice straw. However, it could not be known whether such inhibitors were high or low molecular and organic or inorganic matters. Therefore, further fractionation of $\mathrm{HCl}$ extract was carried out (Fig. 4). The inhibitory-effect of each resultant fraction, namely RM, RP, RA, H1A, RPa, RMn, and RMda, was recorded in Table 6. Sodium chloride formed from the neutralization of $\mathrm{HCl}$ extract was also included. Obviously, sodium chloride was not the inhibitor because it did not inhibit the peracetic acid delignification of beech wood meal. All other fractions, except RMn, did contain of forbidding materials whose existences and intensities were marked with + in Fig. 4. This can explain why fractions $\mathrm{H} 2$ and H3 had the same inhibitory-effect against the peracetic acid delignification of beech wood meal. Since there was precipitate in fraction $\mathrm{H} 2$ and, as given in Table 6, precipitate has showed inhibitory-effect, it was therefore made understandable the above phenomena.

Because fractions RM, RMd, RA, RMda, and RPa were involved in the inhibition of the peracetic acid delignification of beech wood meal, it could then be concluded, in part, that such inhibitors were inorganic matters and soluble partly in water. It was also observed that H1A, RA, RMda, and RPa had more inhibitory-effect than H1, RM, RMd, and RP. This is probably due to their increasing activities upon ignition. 
Table 6. The inhibitory-effect of various fractions in Fig. 4.

\begin{tabular}{|c|c|c|}
\hline Fractions & Degree of delignification (\%) & Inhibitory-effect $(\%)$ \\
\hline \multicolumn{3}{|l|}{$\mathrm{H} 1$} \\
\hline $\mathrm{RM}$ & 28.924 .3 & 17. 18.10 \\
\hline $\mathrm{RP}$ & 16.3 & 20.0 \\
\hline RMd & 38.1 & 14.8 \\
\hline $\mathrm{RMn}$ & 98.3 & 0.4 \\
\hline $\mathrm{H} 1 \mathrm{~A}$ & 19.7 & 19.2 \\
\hline RA & la. 0 & 19.6 \\
\hline $\mathrm{RPa}$ & 15.1 & 20.3 \\
\hline RMda & 20.9 & la. 9 \\
\hline Control* & 95.0 & 1.2 \\
\hline
\end{tabular}

* Original lignin content of beech: $23.9 \%$

H1A, RA, RPa, RMda were ashes of $\mathrm{H} 1, \mathrm{RM}, \mathrm{RP}, \mathrm{RMd}$, respectively.

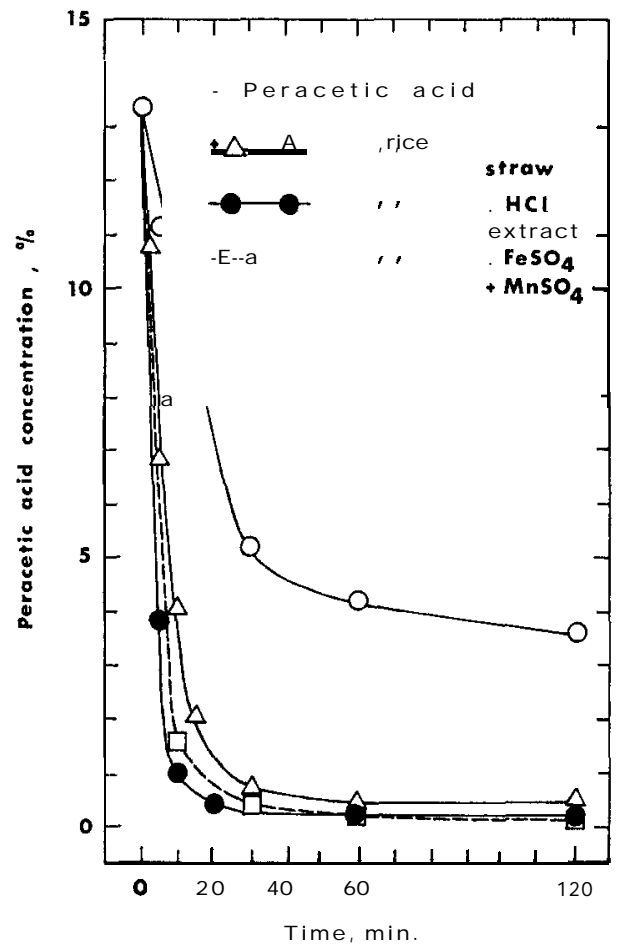

Fig. 5. Decomposition rate of peracetic acid.

\section{Identification of inhibitors}

Attempts were made to identify the function of inhibitors in the course of the peracetic acid delignification. Peracetic acid was then mixed with rice straw or HCI extract or ash from $\mathrm{HCl}$ extract at $\mathrm{pH} 3.75$ and the decomposition rate of such peracetic acid mixtures was measured at $80^{\circ} \mathrm{C}$ (Fig. 5). It is evi- 
dent that the decomposition rate of the mixture of peracetic acid with HCI extract or ash from HCI extract was the highest. Therefore inhibitors have acted as catalysts in the increase of decomposition rate of peracetic acid and hence rice straw's peracetic acid delignification was not accomplished completely. It is interesting to note that ash of $\mathrm{HCl}$ extract gave a reddish color during the early moment of the reaction with peracetic acid and a reddish-purple color at the end of the reaction.

Since inhibitors were inorganic matters as mentioned above, the resistances of various metals were investigated. Metal dosage was arbitrarily chosen as $4.8 \%$, a percentage equal to the ash content of HCI extract. Preliminary runs showed that $\mathrm{Mg}, \mathrm{Ca}, \mathrm{K}, \mathrm{Al}, \mathrm{P}, \mathrm{Zn}, \mathrm{Pb}$, and $\mathrm{Na}$ had no inhibitory-effect upon the peracetic acid delignification of beech wood meal. $\mathrm{Fe}^{2+}, \mathrm{Fe}^{3+}, \mathrm{Cu}^{2+}$, $\mathrm{Mn}^{2+}$, and Si (as water glass), however, exhibited a clear resistance to the peracetic acid delignification of beech wood meal with their intensities decreased in that order. In the above experiment, $\mathrm{MnSO}_{4}$ was used as the sample of manganese because it was reported that maganese was likely to be absorbed by plants as the divalent cation (Adams, 1965).

Table 7. Delignification degree of the HCl-extracted non-woody plants at peracetic acid dosage of $100 \%$.

\begin{tabular}{lccc}
\hline \multirow{2}{*}{ Samples } & \multicolumn{3}{c}{ Degree of delignification $(\%)$} \\
\cline { 2 - 4 } & Unextracted & HCl-extracted & Gain \\
\hline Rice straw & 23.1 & 64.0 & 40.9 \\
Bamboo & 31.5 & 84.3 & 52.8 \\
Barley straw & 67.4 & 81.3 & 13.9 \\
Bagasse & 80.2 & 91.7 & 11.5 \\
\hline
\end{tabular}

Besides, HCI-extracted bamboo, rice straw, barley straw, and bagasse showed a perfect delignification with peracetic acid (Table 7). Moreover, only the HCI extracts of rice straw and bamboo indicated the inhibitions against the per. acetic acid delignification of beech wood meal (Table 8). By combining these facts, the contents of $\mathrm{Fe}^{*}+, \mathrm{Fe}^{3+}$, total iron, copper, manganese, and silica in the $\mathrm{HCl}$ extracts of four non-woody plants examined were determined (Table 8). Beech wood meal was then mixed with an amount equal to the determined percentage of each inhibitory-effect-having-metal of rice straw's $\mathrm{HCl}$ extract prior to its peracetic acid treatment. Results indicated that only iron inhibited the peracetic acid treatment of beech (Table 9). Hence, it could be concluded that the reason why rice straw was not delignified satisfactorily by peracetic acid was fundamentally due to its extractable iron compound $(0.020 \%)$ which existed as both $\mathrm{Fe}^{2+}$ and $\mathrm{Fe}^{3+}$ in about half amount each.

It was experimentally found out that under $0.01 \%$ limit, iron would not inhibit the peracetic acid treatment. Above this limit, peracetic acid delignification would be decreased markedly (Fig. 6).

Also it was observed that $\mathrm{HCl}$-soluble iron content of bamboo was the same as that of rice straw (Table 8). Hence, bamboo was found to be difficult to 
Table 8. Metal content and inhibitory-effect of the $\mathrm{HCl}$ extracts of four non-woody plants.

\begin{tabular}{|c|c|c|c|c|c|c|c|c|}
\hline \multirow{2}{*}{ Samples } & \multicolumn{2}{|c|}{ Total iron $(\%)$} & \multirow{2}{*}{$\begin{array}{l}\mathrm{Fe}^{2+} \\
(\%)\end{array}$} & \multirow{2}{*}{$\begin{array}{l}\mathrm{Fe}^{3+} \\
(9)\end{array}$} & \multirow{2}{*}{$\begin{array}{l}\mathrm{Mn}^{2+} \\
(9)\end{array}$} & \multirow{2}{*}{$\begin{array}{l}\mathrm{Cu}^{2+} \\
(\%)\end{array}$} & \multirow{2}{*}{$\begin{array}{l}\mathrm{Si}^{*} \\
(\%)\end{array}$} & \multirow{2}{*}{$\begin{array}{c}\text { Inhibitory } \\
\text { effect } \\
(\%)\end{array}$} \\
\hline & Color & A A & & & & & & \\
\hline RS exti & 0.019 & 0.0 & .0091 & 0.010 & 0.071 & + & 1.40 & 18. 1 \\
\hline BB extract & 0.018 & 0.019 & 0.013 & 0.005 & 0.0032 & 0.0005 & 0.08 & 16.3 \\
\hline BS extract & 0.009 & 0.0087 & 0.0075 & 0.0015 & 0.0012 & 0.0017 & 0.70 & 2.0 \\
\hline BG extract & 0.007 & 0.0082 & 0.0061 & 0.001 & 0.0015 & 0.0003 & 0.30 & 2. 2 \\
\hline
\end{tabular}

RS, rice straw; BB. bamboo ; BS, barley straw ; BG, bagasse ; Color, colorimetric method; AA, atomic absorption method.

+ : trace

* Determined as the difference of the silica content in original and HCl-extracted samples.

Table 9. Inhibitory-effect of iron and its mixtures on the peracetic acid delignification of beech wood meal.

\begin{tabular}{|c|c|c|c|}
\hline \multirow{2}{*}{ Metals } & \multirow[b]{2}{*}{ Dosage $(\mathscr{O})$} & \multicolumn{2}{|c|}{ Inhibitory-effect $(\%)$} \\
\hline & & $\begin{array}{l}\text { Before } \\
\text { ignition }\end{array}$ & $\begin{array}{c}\text { After } \\
\text { ignition }\end{array}$ \\
\hline $\begin{array}{l}\mathrm{FeSO}_{4} \\
\mathrm{FeSO}_{4} \\
\mathrm{FeSO}_{4} \\
\mathrm{FeCl}_{3} \\
\mathrm{MnSO}_{4} \\
\mathrm{Water} \mathrm{glass} \\
\mathrm{FeSO}_{4}+\mathrm{MnSO}_{4} \\
\mathrm{FeSO}_{4}+\mathrm{FeCl}_{3} \\
\mathrm{FeCl}_{3}+\mathrm{MnSO}_{4} \\
\mathrm{FeSO}_{4}+\mathrm{FeCl}_{3}+\mathrm{MnSO}_{4} \\
\mathrm{FeSO}_{4}+\mathrm{MnSO}_{4}+\mathrm{Water}_{\text {glass }} \\
\mathrm{FeSO}_{4} * \\
\mathrm{FeSO}_{4}+\mathrm{MnSO}_{4} *\end{array}$ & $\begin{array}{l}0.007 \\
0.009 \\
0.020 \\
0.020 \\
0.071 \\
1.40 \\
0.020+0.071 \\
0.011+0.009 \\
0.020+0.071 \\
0.011+0.009+0.071 \\
0.020+0.071+1.40 \\
0.020 \\
0.020+0.071\end{array}$ & $\begin{array}{r}2.3 \\
16.7 \\
15.8 \\
0.6 \\
0.6 \\
18.2 \\
13.4 \\
14.7 \\
18.3 \\
18.7 \\
4.1 \\
11.8\end{array}$ & $\begin{array}{l}\text { ND } \\
\text { ND } \\
0.2 \\
0.3 \\
0.7 \\
\text { ND } \\
13.5 \\
0.4 \\
9.6 \\
7.8 \\
0.5 \\
\text { ND } \\
\text { ND }\end{array}$ \\
\hline
\end{tabular}

ND, not determined.

* Peracetic acid dosage was $400 \%$. The others were carried out at peracetic acid dosage of $150 \%$.

delignify at low peracetic acid dosages ( $\leqq 300 \%)$ (Fig. 2). However, since it could be delignified successfully at high peracetic acid dosages ( $\geqq 400 \%$ ), it should be said that other factors must be involved in the inhibition of the peracetic acid delignification of rice straw. In other words, extractable iron compound was merely a principal inhibitor of the peracetic acid delignification.

As mentioned above, $\mathrm{HCl}$ extract of rice straw contained of manganese salt and silica (Table S), though these metals alone did not inhibit the peracetic acid delignification of beech wood meal at their determined percentages.

However, a mixture of iron and manganese or iron, maganese, and silica showed a higher hindrance effect upon the peracetic acid delignification than did iron alone (Table 9).

At peracetic acid dosage of $400 \%$, the delignification percentage of a mix- 


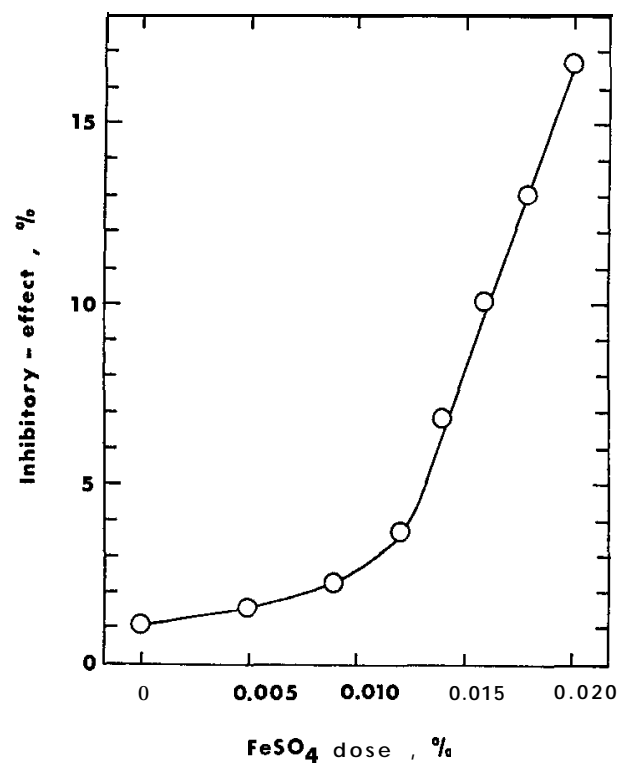

Fig. 6. Inhibitory-effect of $\mathrm{FeSO}_{4}$ dose against the peracetic acid delignification of beech.

ture of ferrous sulfate and beech wood meal was $80 \%$ (Table 9). This was generally the same as that of moso bamboo's delignification percentage (94.1\%) at the same peracetic acid dosage. Therefore, it is understandable why bamboo was delignified difficultly at low peracetic acid dosages. Also, since the delignification percentage of beech wood meal mixed with ferrous sulfate and manganese sulfate at a peracetic acid dosage of $400 \%$ was $50 \%$ (Table 9), a similar percentage to that of rice straw at the same peracetic acid dosage, it can certainly be said that manganese salt was a co-inhibitor of the peracetic acid delignification of rice straw. Such a conclusion was supported by the fact that a combination of ferrous sulfate and manganese sulfate did show a clear inhibition against the peracetic acid delignication of beech wood meal even after ignition, while other metals did not (Table 9). This result may explain, in part, why fractions H1A, RA, RMda, and RPa had higher inhibitory-effect on the peracetic acid delignification than fractions H1, RM, RMd, and RP, as already mentioned above. Hence it was thought that manganese has played a great role in the survived inhibitory-effect of ignited iron.

From the above results, it would be concluded that iron compound was the principal inhibitor of the peracetic acid delignification of rice straw and bamboo. Manganese salt, in particular, was the co-inhibitor in addition to iron compound, of the peracetic acid delignification of rice straw. 


\section{REFERENCES}

Adams, F. 1965 Mangant se. In "Methods of Soil Analysis," ed. by C. A. Black, American Society of Agronomy, Inc., Madison, Wisconsin, U.S.A., p. 1014

Ai, T. V., K. Sakai and T. Kondo 1977 Studies on the holopulp. I. A comparison of the papermaking properties of holopulp and conventional chemical pulp. J. Fuc. Agr., Kyushu Univ., 21(2・3): 79-90

Browning, B. L. 1967 Methods of Wood Chemistry. Vol. 1. 1st ed., Interscience, New York, pp. 80,82 , and 87

Poljak, A. 1948 Holzaufschluß mit Peressigsäure. Angew. Chem., 60A(2): 45-46

Wise, I,. E., M. Murphy and A. A. d'Addieco 1946 Chlorite holocellulose, its fractionation and bearing on summative wood analysis and on studies on the hemicelluloses. Paper Trade $J ., \mathbf{1 2 2}(2): 35-43$ 